\title{
Implementation of MS1500: 2009: A Gap Analysis
}

\author{
Salina Daud ${ }^{1}$, Rohayati Che Din ${ }^{2}$, Suzaida Bakar ${ }^{1}$, Mohd Ridzuan Kadir ${ }^{1}$ and Noraina \\ Mazuin Sapuan ${ }^{1}$
}

${ }^{1}$ College of Business Management and Accounting, Universiti Tenaga Nasional, Malaysia

${ }^{2}$ IKIP International College, Pahang, Malaysia

\begin{abstract}
A comprehensive halal food guideline known as Malaysia Standard Halal Food Guidelines (MS 1500: 2009) was launched in 2004. This standard is a new concept in marketing as well as a quality benchmark for producers. The objective of the study is to analyse the gap between importance and performance factors in the implementation of MS 1500: 2009 Halal food guidelines in Malaysia. Survey questions were distributed to managers or supervisors of selected Halal companies located at two Halal Hubs in Malaysia. Findings suggest that the companies in the sample should target improvements of the premises' layout in the implementation of MS 1500: 2009 standard. Besides that, these companies shall also focus on the factor that relates to the processing of Halal food. The results indicate that the use of the importance-performance analysis in evaluating the implementation of MS 1500: 2009 standard can identify how companies implement this standard effectively.
\end{abstract}

Keywords: Malaysian Halal Food Standard, Importance-performance Analysis, Food Industries

\section{Introduction}

Malaysia has undertaken measures to support the development of its halal industry as identified in the Second Industrial Master Plan (1996 - 2005) and The National Agricultural Policy (1998 - 2010). The Government has set aside almost RM100 million in IMP3 to help boost efforts to make Malaysia an international halal hub. The strategic thrust to make Malaysia an international halal food hub has been reiterated in every budget speech for the last few years (Othman, 2008). The halal industry is touted as a new growth sector for Malaysia in light of the huge potential of this market. The Prime Minister Datuk Seri NajibTun
Razak said at the launching of the Sixth International Halal Showcase 2009, "The opportunities in the halal sector are huge and should be explored to the fullest". Datuk Seri Najib shared the same view with Malaysia's two previous prime ministers in regard to positioning the country as an International Halal Food Hub.

It is part of the government strategies to promote Malaysia Halal Food Standards MS1500: 2009 to the world. Successful recognition and world acceptance of the Malaysia Halal Standard is important to facilitate Malaysian potential food producers and exporters to gain control over global halal market. Malaysia halal food program

Copyright (C) 2011 Salina Daud, Rohayati Che Din, Suzaida Bakar, Mohd Ridzuan Kadir and Noraina Mazuin Sapuan. This is an open access article distributed under the Creative Commons Attribution License unported 3.0, which permits unrestricted use, distribution, and reproduction in any medium, provided that original work is properly cited. Contact author: Salina Daud. E-mail: salina@uniten.edu.my 
started as early as 1980s with the establishment of Trade description Act 1972 comprising two orders: Trade Description Order (the usage of halal) and Food labelling, 1975. In 2004, a comprehensive halal food guideline known as Malaysia Standard MS1500:2004 Halal Food Guidelines was established. In 2009 the standard was revised. Today Malaysia Halal Food Standard is known as MS1500: 2009.

The ultimate success and credibility of the Malaysia Halal Food Standard MS1500: 2009 at the domestic or international level will depend on whether all parties involved in the food production implement the halal food guidelines requirements completely or not. Food producers that have applied for halal certificate have to adhere to halal requirements to prevent from nonimplementation incidences. Besides, consumer may misinterpret the halal standard requirements when companies partially comply with the standard. Stringent implementation of the halal standard leads to consumer trust in halal products. Consumer trust in the halal product is important because it affects the brand that is associated with the halal product (packaging), the farmers that produce/provide the raw materials, the companies that process and supply the products, or the country from which the products originate. Needless to say, Halal food production involves the whole system, from the government regulatory agencies, the producers, the supplying companies, the transportation systems, and all the intermediaries including the agents or distributors.

Much hope was put forward by the government to see the successful implementation of MS1500: 2009 halal food guidelines by Malaysian food producers. Still there are lots of complaints of partial implementation to the guidelines by errant food producers. The number of cases of implementation infractions involving Malaysian food producers varies greatly. During the period 1982 to 2008, about 40 cases of non-compliance with MS1500: 2009 halal food guidelines were brought before JAKIM, the governing body authorised to oversee Halal certification (jakim.com.my). More non-implementation of halal guidelines by food producers were reported in mainstream newspaper of being late. Variation in Food Act and Food Safety Guidelines compliance has often been attributed to particularistic aspects of food producers during implementation (Fernandez-Martin, 1996; Early, 2002). A number of studies on Food Act and Food Safety Guidelines compliance, for example Goldstein (2003) has pointed to the importance of several factors in implementation stages.

The implementation of Malaysia Standard MS1500: 2009 Halal Food Guidelines has not been subject to many empirical studies in Malaysia. A few studies were done on halal food branding (Shahidan and MdNor, 2006), halal products from the consumers perception (Nuradli et al., 2007), quality assurance in halal food (Hayati et al., 2008), value chain of halal certification system (Nurulhuda et al., 2009), and the concept of Theory of Planned Behavior in halal food purchasing (Syed Shah and Nazura, 2011). Beside these few studies on halal food production, there have not been any studies done yet on halal food guidelines implementation. The purpose of this study is to identify to what extent the MS 1500: 2009 has been implemented by food producers and to analyse the gap between importance and performance factors in the implementation of MS 1500: 2009 Halal food guidelines in Malaysia. This study differs from previous studies on Food Act or Food Safety Guidelines because companies' compliance with Food Safety Act or Food Safety Guidelines is compulsory and mandatory. In the case of halal compliance, it is not so. The food businesses can opt to comply with the halal guidelines by applying for halal certification and only food companies awarded with halal certifications are required to comply with all halal procedures and requirements. . 


\section{MS1500: 2009 Halal Food Guidelines}

Malaysia Standard MS1500: 2009 Halal Food Guidelines is a policy to guide Production, Preparation, Handling and Storage of halal food products in Malaysia. The standard is a first revision of MS1500:2004 which was based on a previous standard developed by SIRIM known as MS1500: 2000. Malaysia Standard MS1500: 2009 Halal Food Guidelines covers the guidelines of Food Safety Principle (MS1514), Hazard Analysis Critical Control Point (HACCP-MS1480) as well as the guidelines for good hygienic practice (GNP) and Sanitation Standard Operating Procedures (SOPs). The guidelines not only fulfil the halal requirement, but also maintain standards that meet global benchmark such as ISO 9000 and Codex Alimentarius and Hazard Analysis Critical Control Point (HACCP).

MS1500: 2009 Halal Food Guidelines is based on Islamic law. Source of Islamic law is AlQu'ran, a divine book revealed to Prophet Muhammad from Allah the Creator, "today I have perfected for you your religion and completed my favour upon you and have chosen for you Islam as your religion" AlQuran verse 124. Dr Yusof al Qardawi, an Islamic scholar, divided Islamic law into two main sections, Al-ibadat and Al-mu'amalat. Dietary law (food and drinks, including ritual slaughtering and hunting) is included in the Al-mu'amalat section. Islamic dietary law dictates that Muslim may only eat halal and wholesome food as stated clearly in AlQu'ran, Surah Al-Baqarah, verse 168, “O ye people! Eat of what is on earth, halal and good, and do not follow the footsteps of the Evil One, for he is to you an avowed enemy". In the above mentioned verse, the word good is being associated with the word halal to emphasise the importance of wholesomeness in food. In Muslim perspectives, all halal products must also be necessarily good. In other words, halal carries the notion of wholesomeness of the products so that their consumption may lead to the well-beings of mankind in general.
According to Sumali (2006), halal and good food means food that is permitted under the Shariah law which fulfils the following conditions:

- The food or its ingredients do not contain any parts or products of animals that are non halal to Muslims by Shariah law or products of animals which are not slaughtered according to Shariah law;

- The food does not contain any ingredients that are najis according to Shariah law. The food is safe and not harmful, and cleaner;

- The food is not prepared, processed or manufactured using equipment that is contaminated with things that are Najis according to Shariah law;

- The food or its ingredients do not contain any human parts or its derivatives that are not permitted by Shariah law; and

- During preparation, processing, packaging, storage or transportation, the food is physically separated from any other food that does not meet the definitions stated in the items above or any other things that have been decreed as Najis by Shariah law.

Yaakobet al. (2007) point out that halal and good food concept leads to three important guidelines in the selection of food and drinks in Islam. They comprise;

(I) whether the consumption of the foodstuff is prohibited by Allah s.w.t;

(II) whether the foodstuff is obtained through halal or haram means and

(III) whether or not the material is harmful to health.

According to Othman (2008), companies producing halal products alone will not make it to the top. He points out that food must also be "thoyyiban", which encompasses quality. In other words, food must be 
nutritious and hygienic, and manufacturers must ethically deliver what consumer wants. Yaakobet al. (2007) argue that quality halal food concept and requirements are comprehensive, covering the whole food production process. It begins from farm stage and continues to the next levels of production process until the product goes into the customers' hands. According to a recent research, it has been found that MS1500: 2009 Halal Food Guidelines is a comprehensive standard and recognised as a new concept in marketing as well as a quality benchmark (Shahidan and MdNor, 2006).

\section{Implementation of MS1500: 2009 Halal Food Guidelines}

Winter (1990) defined implementation as the "make or break"stage of a program. According to Winter (1990) and Lipsky (1976), successful implementation process leads to successful program outcomes. Various authors found different conditions constraint policy outcomes. Pressman and Wildavsky (1973) feel perception of program intentions by various stakeholders affect program outcome. Elmore et al. (1987) on the other hand, identifies inadequacy of resources, whereas ineffective organisational structure (Schneider et al., 1990; Sabatier and Mazmanian, 1980) and inability to create sustaining political linkages (Yanow, 1987) constraints program outcomes. Winter and May (2001) argue that successful implementation depends on the interrelationship among actors in the various stages of implementation. Ingraham (1997) indicates there is seldom a perfect fit between problems as defined by legislation, the design of program aimed at alleviating it, and the implementation delivered by that program. Researchers on policy implementation agree that implementation is the key to achieve the goals of a policy (Pressman and Wildavsky, 1973; McLaughlin, 1987; Lipsky, 1976; Sabatier and Mazmanian, 1980; Elmore, et al., 1987; Yanow, 1987).

The implementation of Food Act and Food Safety regulation was a subject to very few studies (Hutchinson and Chaston, 1995). Yapp and Fairman (2005) studies on Food Safety and Food Act Regulation implementation concluded that poor knowledge and awareness of regulations are major factors contributing to nonimplementation of policies and procedures stipulated by the act. Another study by Wright (1998) and Taylor (2001) noted lack of trust in the legislation as reason for nonimplementation of the policy. Lack of trust in the enforcement officers is also found to be one of the factors contributing to noncompliance of food safety and Food Act regulation by Taylor (2001) and Yapp and Fairman (2005).

Just as the studies on the implementation of Food Act and Food Safety regulation are few, so are the studies on the implementation of Malaysia Standard MS1500: 2009 Halal Food Guidelines. The implementation of MS1500: 2009 requirements are inherently difficult, involving challenges that frequently lead to unsuccessful execution. In an example of a successful effort by Nestle Malaysia, it was observed that during their initial initiative to implement the halal program, the halal systems were reinforced by bureaucracy, service organisations, policies, regulations, personnel and training, as well as funding (Othman, 2008). Their implementation strategies were complex and had to address a long list of barriers that were uniquely adapted to overcome the implementation problem. Every aspect of implementation is fraught with difficulty, from system transformation to changing service provider behaviour and restructuring organisational contexts.

\section{Importance-Performance Analysis}

The important-performance concept is based on multi-attribute models. This technique identifies the performance of an attribute that can be changed without affecting the importance of the attribute (Kitcharoen, 2004). According to Nale et al. (2000), a particular application of the technique starts with an identification of the attributes that 
are relevant to the choice situation investigated. This approach, also known as quadrant analysis, was introduced by Martilla and James (1977), and focuses on pinpointing those quality and service elements that; a) are most important to customers and/or are likely to make the strongest contribution to overall customer satisfaction and loyalty; and b) are in need of improvement because customers' evaluations of the company's performance on these elements are relatively unfavourable (i.e. customers are dissatisfied and/or perceive that the company's performance is in need of improvement). By using the central tendency measure such as mean, performance scores are ordered and classified into high or low categories, and then by pairing these two sets of rankings, each attribute is placed into one of the four quadrants that will be displayed graphically using an importance-performance matrix.

The important-performance matrix consists of four quadrants; concentrate here, keep up the good work, low priority and possible overkill (O'Neill and Palmer, 2004).First, the 'keep up the good work' quadrant (high importance, high performance) assumes that all elements or attributes that fall in this quadrant are to be key drivers of consumer satisfaction/preference, and the management's job is to ensure that the organization continues to deliver or perform well in these areas. Second, the 'concentrate here' quadrant (high importance, low performance) assumes that all elements or attributes that fall in this quadrant are the key drivers of consumer satisfaction or preference and should be viewed as critical performance shortfalls. It is the management's responsibility to ensure that adequate resources are allocated to these attributes to improve performance in these areas. These areas are priorities for improvement. Third, the 'low priority' quadrant (low importance, low performance) assumes that all elements or attributes are relatively unimportant, such that poor performance should not be given a great deal of priority or attention by management. The last quadrant is the 'possible overkill' (low importance, high performance) assumes that all elements or attributes that are relatively unimportant, should be viewed as an area of performance "overkill" and management may want to redirect resources from these elements to high-priority areas in need of improved performance.

With little modification, importantperformance analysis (IPA) has been applied to a diverse range of contexts including hospital services (Yavas and Shemwell, 2001), tourism management (Wade and Eagles, 2003), education (Nale et al., 2000; O'Neill and Palmer, 2004) and service quality (Ennew et al., 1993; Ford et al., 1999). Hansen and Bush (1999) pointed out that IPA is a simple and effective technique that can assist practitioners in identifying improvement priorities for service attributes and direct quality-based strategies. In addition, Hawes and Rao (1985) pointed out that IPA is also being used in identifying improvement opportunities and guiding strategic planning efforts.

\section{Material and Method}

A cross sectional methodology was employed in this study where managers or owners of Selangor Halal Hub and Port Klang Free Zone $\mathrm{Hub}$ in Malaysia were selected as respondents for this research. A survey instrument that has a 1-5 Likert scale was designed and it consisted of two main sections. Section A focused on respondents' profile and Section B focused on the level of importance and performance of each MS 1500: 2009 dimensions. The dimensions for MS 1500: 2009 include management responsibility; premises; devices, utensils, machines and processing aids; hygiene, sanitation and food safety; processing of halal food; storage, transportation, display, sale and servings of halal food; packaging, labelling and advertising and legal requirements. All variables were checked on the reliability and validity criterion and all met the validity and reliability requirements. IPA will be used in this study to analyse the 
gap between importance and performance factors in the implementation of MS 1500: 2009 Halal food guidelines in Malaysia.

\section{Results and Discussion}

\section{Respondents' Profile}

A total of 70 Halal Certified Companies located in Selangor Halal Hub and Port Klang Free Zone Hubwere taken as a sample. Of these, $50 \quad(71 \%)$ completed survey questionnaires were collected. Since this is a pilot study, small sample is enough to run the analysis. All the samples chosen for the pilot study were from the same population in the actual survey (Malhotra and Birks, 1999). Majority of the companies have more than 200 employees (44\%) and $90 \%$ of these companies have more than $50 \%$ of Muslim employees. $76 \%$ of these companies have sent their staff for Halal Certification (MS 1500: 2009) training. However $88 \%$ of these companies sent their staff to Halal Certification Training less than 2 times in a year. $96 \%$ of these companies produce only halal products, while $4 \%$ of them produce both halal and non-halal products.

\section{Reliability Analysis}

The reliability of the data was verified using Cronbach alpha, where the closer the Cronbach alpha is to 1 , the higher the internal consistency reliability (Sekaran, 2000). The alpha coefficients for this study are all above 0.70 and were concluded as being reliable (Hair et al., 2006; Nunnally, 1978). Table 1 presents the Cronbach alpha coefficient for each dimension.

Table 1: Coefficient of Cronbach Alpha for Importance and Actual Performance Scale

\begin{tabular}{|c|l|c|c|c|}
\hline No. & \multicolumn{1}{|c|}{ Dimensions } & Importance & $\begin{array}{c}\text { Actual } \\
\text { Performance }\end{array}$ & $\begin{array}{c}\text { No. of } \\
\text { items }\end{array}$ \\
\hline 1 & Management responsibility & .96 & .91 & 9 \\
\hline 2 & Premises & .90 & .92 & 10 \\
\hline 3 & Devices, utensils, machines and processing aids & .78 & .71 & 5 \\
\hline 4 & Hygiene, sanitation and food safety & .96 & .93 & 10 \\
\hline 5 & Processing of halal food & .97 & .98 & 9 \\
\hline 6 & $\begin{array}{l}\text { Storage, transportation, display, sale and } \\
\text { servings of halal food }\end{array}$ & .96 & .94 & 4 \\
\hline 7 & Packaging, labelling and advertising & .93 & .98 & 9 \\
\hline 8 & Legal requirements & .92 & .85 & 4 \\
\hline
\end{tabular}

\section{Gap Analysis}

Table 2 presents a summary of managers'/owner's importance-performance means for 8 scale items. The negative gap value between importance-performance means reflects that the companies' performances have not met the importance attributes of the MS 1500: 2009 standard. In other words, companies selected in the study were under performing significantly in all dimensions that rated important in MS 1500: 2009 standard. 
Table 2: Summary of Means

\begin{tabular}{|c|l|c|c|c|}
\hline No. & \multicolumn{1}{|c|}{ Dimensions } & Importance & $\begin{array}{c}\text { Actual } \\
\text { Performance }\end{array}$ & Gap (P-I) \\
\hline 1 & Management responsibility & 4.66 & 4.43 & -.23 \\
\hline 2 & Premises & 4.74 & 4.35 & -.39 \\
\hline 3 & $\begin{array}{l}\text { Devices, utensils, machines and processing } \\
\text { aids }\end{array}$ & 4.53 & 4.36 & -.17 \\
\hline 4 & Hygiene, sanitation and food safety & 4.73 & 4.63 & -.10 \\
\hline 5 & Processing of halal food & 4.77 & 4.56 & -.21 \\
\hline 6 & $\begin{array}{l}\text { Storage, transportation, display, sale and } \\
\text { servings of halal food }\end{array}$ & 4.84 & 4.72 & -.12 \\
\hline 7 & Packaging, labelling and advertising & 4.81 & 4.73 & -.08 \\
\hline 8 & Legal requirements & 4.79 & 4.66 & -.13 \\
\hline Overall means & 4.73 & 4.56 & \\
\hline
\end{tabular}

Note: (P-I) value is significant at $\mathrm{p}<0.05$

Figure 1 presents the importanceperformance map of MS 1500: 2009 standards. The data used to construct the importance-performance grid were the overall means of importance and performance for all scale items which are 4.73 and 4.56 respectively. One item falls into the "concentrate here" quadrant (high importance/low performance) which is premises. Companies need to take immediate action on this dimension that focuses on layout of premises that facilitates products process flow from receipt of raw materials to finished products, layout that facilitates cleaning and proper supervision of food hygiene, layout that has adequate sanitary facilities, and layout with loading and unloading bay to allow effective transfer of perishables products. The premises should also be kept in good repair and condition to prevent pest access, the premises shall be effectively separated from pig farm or its processing activities, the premises shall be dedicated for halal slaughtering and processing only, and the premises shall be refrained from pets and other animals.

Three items were located in the quadrant "keep up the good work" (high importance/high performance), which are:

1) storage, transportation, display, sale and servings of halal food;
2) packaging, labelling and advertising; and

3) legal requirements.

These three attributes are the strength dimensions possessed by the companies in the sample, which means that these companies really put into operation these three dimensions.

Two attributes that fall in the "low priority" (low importance/low performance) quadrant are in relation to management responsibility; and devices, utensils, machines and processing aids. This indicates that both of these dimensions do not require immediate resource allocation as they are performing at the level appropriate to the importance attached to them at the present time. However, the companies should hold in reserve resources to cope with a possible change of importance attached to them due to changes in the business environment in the future.

There is one item that falls neither into the "concentrate here" quadrant nor into the "keep up the good work" quadrant, namely processing of halal food dimension. The companies in the sample need to check this dimension from time to time according to business environment. If this dimension later falls under the "concentrate here" quadrant, 
then companies need to take an immediate action to rectify this problem. Another one dimension falls neither into the "keep up the good work" quadrant nor into the "possible overkill" quadrant, that is hygiene, sanitation and food safety dimension. The companies in the sample also need to check from time to time on this dimension. If this dimension later falls into the "possible overkill" quadrant, then the companies need to immediately remove resources allocated to this dimension and redeploy the resources saved to develop dimension located in the "concentrate here" quadrant.

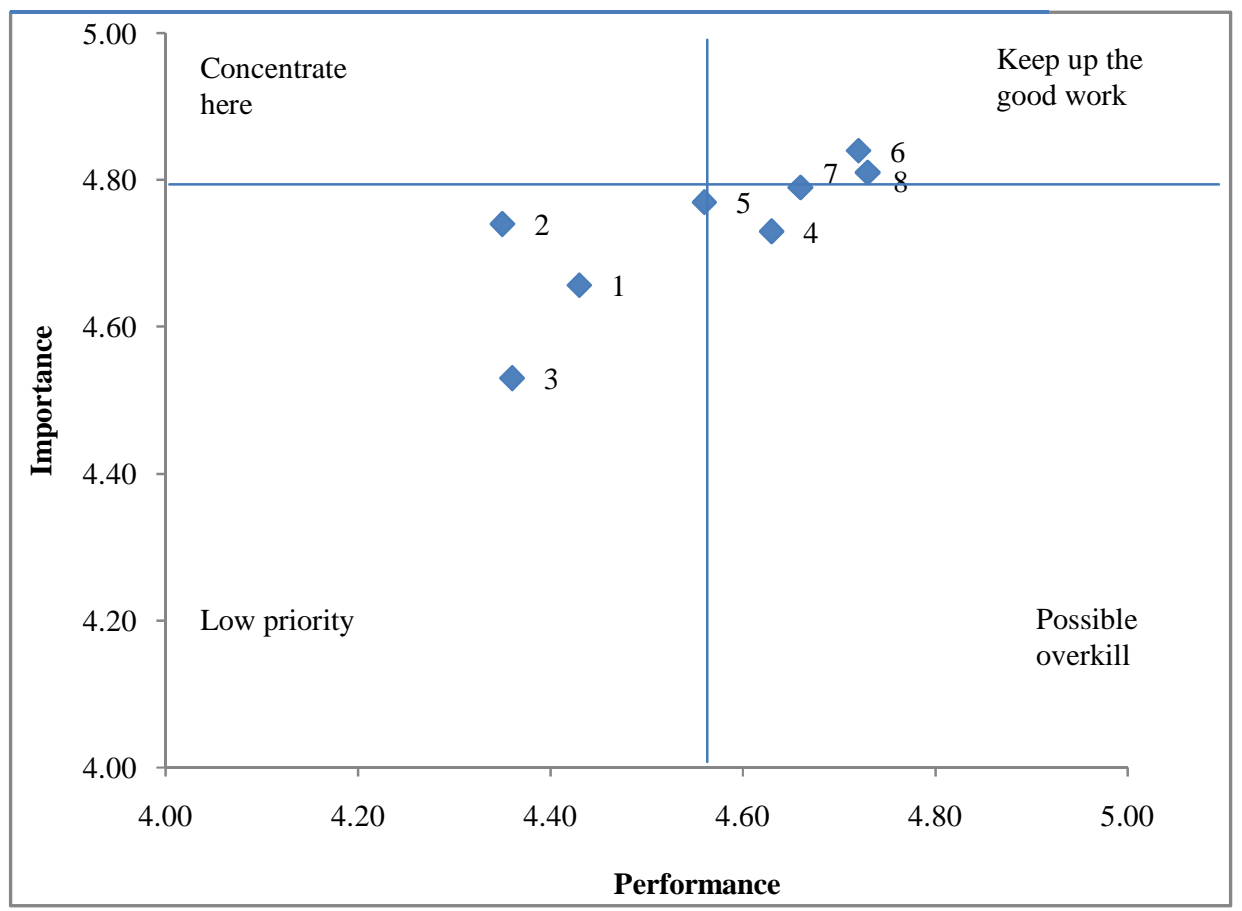

Note: 1- Management responsibility, 2- Premises, 3- Devices, utensils, machines and processing aids, 4Hygiene, sanitation and food safety, 5- Processing of halal food, 6- Storage, transportation, display, sale and servings of halal food, 7- Packaging, labelling and advertising, 8- Legal requirements

\section{Fig1. Importance-Performance Map of MS 1500: 2009 Standards}

\section{Conclusion and Future Research}

As a conclusion, this study suggests that the companies in the sample should target improvements of the premises layout in the implementation of MS 1500: 2009 standard. The premises layout dimension includes layout of premises that facilitates products process flow from receipt of raw materials to finished product; layout that facilitates cleaning and proper supervision of food hygiene; layout that has adequate sanitary facilities; layout with loading and unloading bay to allow effective transfer of perishables products; layout with good condition to prevent pest access; layout that is separated from pig farm or its processing activities, layout that is dedicated for halal slaughtering and processing only, and layout that is refrained from pets and other animals. Besides that, these companies shall also focus on the processing of halal food dimension that falls neither into the "concentrate here" quadrant nor into the "keep up the good work" quadrant. If this item falls into the 
"concentrate here" quadrant, then the companies need to take urgent action.

The results indicate that the use of the IPA in evaluating the implementation of MS 1500: 2009 standard can identify how companies implement this standard effectively. This result also can be used to identify specific problem areas and can help target corresponding improvement efforts. Future research could seek to establish whether a consistent pattern is observable across companies in different Halal Hub and whether the findings will be dissimilar on a larger sample.

\section{References}

Abdul Talib, H. H., Ali, K. A. M. \& Jamaludin, K. R. (2008). "Quality Assurance in Halal Food Manufacturing in Malaysia: A Preliminary Study," Proceedings of International Conference on Mecahnical and Manufacturing Engineering, UniversitiTun Hussein Onn Malaysia, 21-23 May, Johor Bharu, Malaysia.

Alam, S. S. \& Sayuti, N. M. (2011). “Applying the Theory of Planned Behavior in Halal Food Purchasing," International Journal of Commerce and Management, 21(1), 8-20.

Dali, N. R. S. M., Sulaiman, S., Samad, A. A., Ismail, N. \& Alwi, S. H. (2007). "Halal Products from the Consumers Perception: An Online Survey," Proceeding of the Islamic Entrepreurship Conference, KolejUniversiti Islam Malaysia, 19-21st January.

Early, R. (2002). "Food Ethics: A Decision Making Tool for the Food Industry?," International Journal of Food Science and Technology, April, 37(4), 339.

Ennew, C. T., Reed, G. V. \& Binks, M. R. (1993). "Importance-Performance Analysis and the Measurement of Service Quality," European Journal of Marketing, 27, 59-70.

Eskildsen, J. K. \& Kristensen, K. (2006). "Enhancing Importance-Performance
Analysis," International Journal of Productivity and Performance Management, $55,40-60$.

Ford, J. B., Joseph, M. \& Joseph, B. (1999). "Importance-Performance Analysis as a Strategic Tool for Service Marketers: The Care of Service Quality Perceptions of Business Students in New Zealand and the USA," The Journal of Services Marketing, 13, 171-186.

Goldstein, M. (2003). "IMF Structural Programs," In M. Feldstein (Ed.), Economic and Financial Crises in Emerging Market Economies, Chicago: University of Chicago Press.

Hair, J. F., Black, W. C., Babin, B. J., Anderson, R. E. \& Tatham, R. L. (2006). Multivariate Data Analysis (Sixth Edition.). Upper SaddleRiver, New Jersey: Pearson Education Inc.

Hansen, E. \& Bush, R. J. (1999). "Understanding Customer Quality Requirements: Model and Application," Industrial Marketing Management, 28(2), 119-30.

Hawes, J. M. \& Rao, C. P. (1985). "Using Importance-Performance Analysis to Develop Health Care Marketing Strategies," Journal of Health Care Marketing, 5, 19-25.

Hutchinson, A. \& Chaston, I. (1994). 'Environmental Perceptions, Policies And Practices in the SME Sector: A Case Study,' Proceedings of Business Strategy and Environment Conference, 23-24 September.

Ingraham, P.W. (1997). "Play it Again, Sam; it's Still not Right: Searching for the Right Notes in Administrative Reform," Public Administration Review, 57(4), 325-331.

Kitcharoen, K. (2004). "The ImportancePerformance Analysis of Service Quality in Administrative Departments of Private Universities in Thailand," ABAC Journal, 24, 20-46. 
Lipsky, M. (1976). "Toward a Theory of Street Bureaucracy,' in Willis Hawley and Michael Lipsky (Eds.), Theoretical perspectives on urban politics, Englewood Cliffs, New Jersey: Prentice- Hall.

Malhotra, N. \& D. Birks (1999). 'Marketing Research: An Applied Approach,' Upper Saddle-River, New Jersey: Pearson Education Inc.

Martilla, J. A. \& James, J. C. (1977). "Importance-Performance Analysis," Journal of Marketing, 41, 77-99.

Martin, J. M. F. (1996). The EC Public Procurement Rules, Oxford: Clarenden Press.

McDonnell, L. M. \& Elmore, R. F. (1987). "Getting the Job Done: Alternative Policy Instruments," Educational Evaluation and Policy Analysis, 9(2), 133-52.

McLaughlin, M. W. (1987). "Learning from Experience: Lessons from Policy Implementation," Educational Evaluation and Policy Analysis, 9(2), 171-178.

Nale, R. D., Rauch, D. A., Wathen, S. A. \& Barr, P. B. (2000). "An Exploratory Look at the Use of Importance-Performance Analysis as a Curricular Assessment Tool in a School of Business," Journal of Workplace Learning: Employee Counseling Today, 12, 139-145.

Noordin, N., Noor, N. L. M., Hashim, M. \& Samicho, Z. (2009). "Value Chain of Halal Certification System: A Case of the Malaysia Halal Industry," Proceeding of the European and Mediterranean on Information Systems, 13-14 July.

Nunnally, J. C. (1978). Psychometric Theory, 2nd Edition. Boston, MA: McGraw Hill.

O’Neill, M. A. \& Palmer, A. (2004). "Importance-performance Analysis: A Useful Tool for Directing Continuous Quality Improvement in Higher Education," Quality Assurance in Education, 12, 39-52.
Pressman, J. \& Wildavsky, A. (1973). 'Implementation,' Berkeley, California: University of California Press.

Sabatier, P. \& Mazmanian, D (1980). "The Implementation of Public Policy: A Framework of Analysis," Policy Studies Journal, 8(2), 538 - 560.

Sabatier, P. A. (1986). "Top-down And Bottom-Up Approaches to Implementation Research: A Critical Analysis and Suggested Synthesis," Journal of Public Policy, 6, 21-48.

Schneider, A. \& Ingram, H. (1990). "Behavioral Assumptions of Policy Tools," Journal of Politics, 52(2), 510-29.

Sekaran, U. (2000). 'Research Methods for Business: A Skill-Building Approach,' USA: John Wiley and Sons, Incorporation.

Shafie, S. \& Othman, M. N. (2006). "Halal Certification: An International Marketing Issues and Challenges," Retrieved from: www.ctw-

congress.de/ifsam/download/track_13/pap0 0226.pdf.

Sumali, A. (2006). 'Halal-New Market Opportunities,' Proceedings of the 9th Efficient Consumer Response (ECR), Kuala Lumpur Convention Center(KLCC), Malaysia, 15 November 2006. Retrieved from: http://www.islam.gov.my/portal/lihat.php?j akim $=2140$

Taylor, E. (2001). "HACCP in Small Companies: Benefit or Burden?," Journal of Food Safety, 15, 217-222.

Wade, D. J. \& Eagles, P. F. G. (2003). "The Use of Importance-Performance Analysis and Market Segmentation for Tourism Management in Parks and Protected Areas: An Application to Tanzania's National Parks," Journal of Ecotourism, 2, 196-212.

Winter, S. (1990). 'Integrating Implementation Research,' in Dennis J. P. and 
Donald J. C. (Ed.), Implementation and the Policy Process: Opening Up the Black Box, New York: Greenwood Press.

Winter, S. C. \& May P. J. (2001). "Motivations for Compliance with Environmental Regulations," Journal of Policy Analysis and Management, 20(4), 675-698.

Wright, M. S. (1998). "Factor Motivating Proactive Health and Safety Management," Norwich: HSE Contract Research Report CRR 179/1998.

Yaakob, C. M., Jamil, B., Awis, Q. S. \& Ahmad Nizam, A. (2007). 'Halal Hub Opportunities,' Proceeding of the 4th Asian Livestock and Feed Industry, 25 October, Kuala Lumpur, Retrieved from: http://www.livestockasia.com/conference_p aper/slide/yaakob.pdf

Yanow, D. (1987). "Toward a Policy Culture Approach to Implementation," Review of Policy Research, 7(1), 103-115.

Yapp, C. \& Fairman, R. (2005). "Assessing Compliance with Food Safety Legislation in Small Businesses," British Food Journal, 107(3), 150-161.

Yavas, U. \& Shemwell, D. J. (2001). “Modified Importance-Performance Analysis: An Application to Hospitals," International Journal of Health Care Quality Assurance, 14(3), 104-110.

Yussof, O. M. (2008). "Nestle Malaysia: Pioneer in Big Scale Halal Food Manufacturing," Retrieved from:http://www.standardsmalaysia.gov.my /v2/images2/strategic/S\%20\&\%20H\%20ne stle\%20malaysia.pdf. Viewed on 7th May 2001. 